\section{$\underset{\text { hommes }}{\text { \& migrations }}$}

\section{Hommes \& migrations}

Revue française de référence sur les dynamiques

migratoires

\section{6-1287 | 2010}

Les migrations subsahariennes

\title{
Les Secrets
}

Film tunisien de Raja Amari

\section{André Videau}

\section{Q OpenEdition \\ 1 Journals}

\section{Édition électronique}

URL : http://journals.openedition.org/hommesmigrations/1708

DOI : 10.4000/hommesmigrations. 1708

ISSN : 2262-3353

\section{Éditeur}

Musée national de l'histoire de l'immigration

\section{Édition imprimée}

Date de publication : 1 juillet 2010

Pagination : 304

ISSN : 1142-852X

\section{Référence électronique}

André Videau, « Les Secrets », Hommes \& migrations [En ligne], 1286-1287 | 2010, mis en ligne le 29 mai 2013, consulté le 22 septembre 2020. URL : http://journals.openedition.org/hommesmigrations/ 1708 ; DOI : https://doi.org/10.4000/hommesmigrations.1708

Ce document a été généré automatiquement le 22 septembre 2020.

Tous droits réservés 


\section{Les Secrets}

Film tunisien de Raja Amari

André Videau 
1 Avec Satin rouge, son film précédent et premier long-métrage, Raja Amari s'était attiré les foudres des traditionalistes et des féministes. Deux catégories de public antagonistes mais qui donnent de la voix en Tunisie et peuvent avoir des influences néfastes sur la carrière d'une œuvre (voir H\&M 1232, juillet-août 2002). Elle y procédait, à travers de complexes relations mère/fille (Hiam Abbass et Hend El Fahem) et un mélange d'éducation sentimentale et chorégraphique, à une réhabilitation de la danse orientale, plus communément vulgarisée sous le nom de "danse du ventre". Une forme d'art populaire très codifié. Particulièrement apprécié d'un public masculin, oriental comme occidental, et accusé souvent d'entretenir fantasmes et frustrations dans un parfum de scandale.

2 Sur un registre plus romanesque (trois femmes, une mère et ses deux filles, vivent recluses dans les combles d'un château abandonné), mais avec un enchaînement de situations dramatiques extrêmes, Les Secrets, qui avaient été favorablement accueillis à la Mostra de Venise, a offusqué une partie du public et soulevé des protestations officielles au Festival du Caire.

3 Au bout d'un dédale de sentiers et flanqué de donjons à bulbe d'un autre âge, le manoir où vivent Radhia, l'ainée corvéable (Sondos Belhassen), Aïcha la cadette à l'esprit fragile (Hafsia Herzi, promue vedette depuis La Graine et le Mulet d'Abdellatif Khechiche) et leur mère régente autoritaire (Wassila Dari), à l'air de se situer hors du temps et hors du monde. Pas tout à fait, car un réalisme cru s'insinue dans le conte. Il faut bien vivre et Radhia entretient avec l'extérieur des relations mercantiles. Et puis il y a ces visiteurs nocturnes sans doute liés aux anciens propriétaires. Les secrets du passé vont peser plus lourd. Le choc d'un univers austère et répressif avec la licence, la musique techno, le téléphone portable, les talons aiguilles, le déchaînement de la sensualité trop longtemps refoulée...

4 Dans le clair-obscur du huis-clos, on passe des belles au bois dormant à une tragédie proche de celle des sœurs Papin reprise par Jean Genet dans Les Bonnes. Certains n'ont pas supporté. Dommage pour eux. Le film distille un charme envoûtant. 